\title{
Emotywny komponent znaczenia przymiotników negatywnie waloryzowanych w języku rosyjskim
}

\section{The emotive component of negatively valued adjectives in Russian}

\begin{abstract}
The article analyses adjectives excerpted from a dictionary entitled Senses, Emotions and Adjectives of the Russian Language and evaluated by respondents as causing very unpleasant emotions (marked in the dictionary with three minuses). An attempt was made to delineate the emotive component of their meaning on the basis of data from dictionaries providing explanations, as well as those presenting associations, accompanied by contexts of their usage traced in the corpus. The data contributing to the analysis can be employed in order to reconstruct emotional images of the world and national cultural specificity of expressing emotions. Additionally, they can be used to scrutinize and shape emotional competence, while the methodology of delineating the emotive component of meaning with the use of affective expression and their associations can be employed in further research into emotive lexical items.
\end{abstract}

Keywords: emotive adjectives, emotive component of meaning, dictionary of associations, affective, connotative

Joanna Orzechowska, Uniwersytet Warmińsko-Mazurski w Olsztynie, Olsztyn - Polska, joanna. orzechowska@uwm.edu.pl, ORCID ID: https://orcid.org/0000-0001-9458-5991

Wyrażanie emocji w języku jest jednym z najbardziej złożonych problemów w językoznawstwie. Jako skomplikowany fenomen ludzkiej psychiki emocje nie zostały jeszcze dogłębnie zbadane przez współczesną naukę i nie wypracowano jednolitych metod i narzędzi ich analizy. Ponadto językowe reprezentacje emocji, będąc przedmiotem badań usytuowanym na granicy językoznawstwa ogólnego i psychologii, były dotychczas rozpatrywane przez różne działy językoznawstwa i poddawane analizie różnymi metodami.

Pod koniec lat 80. XX wieku zrodziła się nowa dyscyplina naukowa - emotiologia, badająca werbalizację, wyrażenie i komunikowanie emocji (Šahovskij 21-22). Tym samym zakończył się etap naukowych twierdzeń, że lingwistyka nie powinna zajmować się emocjonalną strona języka (Kerbrat-Orecchioni), dlatego że „nie 
ma w języku emocjonalnej leksyki” (Galkina-Fedoruk 104) i „emocje nie wchodzą w strukturę języka" (Zvegincev 51). Przez wiele lat emocjonalność w języku była rozpatrywana jako konotacja semantyczna lub cecha stylistyczna jednostki, a ostatecznie została usankcjonowana na XIV Międzynarodowym Kongresie Slawistów w Berlinie w 1987 roku w wystąpieniu Františka Daneša (Daneš). Obecnie związek emocji i języka wydaje się naturalny i bezsporny. W literaturze naukowej nastał czas stwierdzeń, że w języku wszystko jest emocjonalne (Balli 7), wszystkie wypowiedzi są emocjonalne (Gak), ,przejawienie się emocji zachodzi w każdej wypowiedzi” (Grabias 294), słowo jest powiązane z różnorodnymi procesami psychicznymi, w których emocje i intelekt tworzą nierozerwalną całość (Mâgkova 20) i zauważa się bogactwo środków językowych służących wyrażaniu emocji oraz emocjonalnych zabarwień języków, w tym rosyjskiego (Vežbickaâ 331-332).

Emotiologia bazuje na założeniu psycholingwistów, że język jest emotywny, mimo że emocjonalność wypowiedzi może mieć charakter implicytny. Częściej jednak mamy do czynienia z wypowiedziami eksplicytnymi, jawnie wyrażającymi siłę i zabarwienie uczuć nadawcy. W procesie komunikacji emocjonalność jako zjawisko psychologiczne przekształca się w emotywność - zjawisko językowe. Emotywność staje się punktem wyjścia w opisach zachowań człowieka w lingwistyce kognitywnej (Šahovskij 29). Lingwiści emotiolodzy zakładają, że przyczyną pierwotnych i wtórnych nominacji zawsze były emocje człowieka, a Homo senties poprzedzał Homo loquens. Stąd stwierdzenie, że emocja poprzedzała słowo. Mowa zaistniała nie po to, by opisywać, opowiadać i twierdzić, ale po to, by wyrażać pragnienie i nakazywać, a takie działania nie mogą obyć się bez emocjonalnego kontekstu (Šahovskij 10-17).

W nauce nie istnieje ujednolicona klasyfikacja środków językowych, wyrażających emocje nadawcy, czyli emotywów, podobnie jak nie istnieje ujednolicona klasyfikacja emocji. W najogólniejszych typologiach do emocjonalnej leksyki naukowcy zaliczają środki językowe nazywające uczucia (środki emocjonalne) oraz środki językowe służące do wzmocnienia siły wyrazu (środki ekspresji, środki stylistyczne). Klasyfikacji nazewnictwa ekspresji (wyrażania) emocji dokonał Władysław Lubaś, który wyróżnił ekspresję (i waloryzację) pozytywną (atencja, aprobata, radość, podziw, żart, przychylność) oraz ekspresję (i waloryzację) negatywną lub raczej negatywną (nostalgia, niedowierzanie, niezadowolenie, zniecierpliwienie) (Lubaś 183-202). Podobnej dychotomii podporządkowana jest typologia Stanisława Grabiasa, w której emocje pozytywne i negatywne są podzielone paralelnie na: skierowane na nosiciela stanu oraz zjawiska poza nosicielem stanów emocjonalnych, w tym na osoby i na zjawiska nieosobowe i ich stany (Grabias 298-299).

Inną klasyfikację proponuje Margarita Kožina, która do emotywów zalicza następującą leksykę ekspresyjno-emocjonalną: 1) wyrazy używane w mowie po- 
tocznej, o charakterze familiarnym, niższego rejestru; 2) wyrazy wieloznaczne, które w znaczeniu przenośnym uzyskują ekspresywne zabarwienie i znaczenie oceny; 3) wyrazy, które emocjonalność i ekspresywność uzyskują dzięki słowotwórczym przyrostkom (Kožina 121-122).

W klasyfikacji Jurija Apresjana ekspresywność i emocjonalność związana jest nie tylko z zabarwieniem stylistycznym i oceną. Badacz wyróżnia dwie podstawowe grupy słów: nazywające emocje i nienazywające emocji. Do leksyki bazowej nazywającej emocje zalicza czasowniki (niepokoić się, cieszyć się), rzeczowniki (strach, zachwyt), przymiotniki (niespokojny) i przysłówki (strasznie). Do drugiej grupy zalicza słowa, które w swojej semantyce zawierają wskazanie na stan emocjonalny subiektu, towarzyszący działaniu lub stanowi (kibicować), oraz słowa, które nie nazywają emocji, ale mają bezpośredni związek z nimi (zaczerwienić się 'oblać się rumieńcem z powodu wstydu, zawstydzić się') (Apresân 51). Ludmiła Babienko stworzyła klasyfikację emotywów bazującą na ich przynależności do części mowy: 1) emotywne czasowniki; 2) emotywne rzeczowniki; 3) emotywne przymiotniki; 4) emotywne przysłówki; 5) emotywne wykrzykniki (Babenko 65-70). Lew Nielubin wyróżnił 3 grupy emotywnych wyrazów: 1) wykrzykniki (och!, ach!); 2) wyrazy nazywające uczucia (strach, nienawiść, radość); 3) wulgaryzmy (Nelûbin 122).

W literaturze naukowej funkcjonuje także podział emotywów ze względu na zakres emocji w ich semantyce. Są to afektywy, konotatywy i potencjatywy (Šahovskij 6, 74; Maslečkina 234). Do afektywów zalicza się słowa, których semem składa się tylko z semu (semów) emocjonalności. To są emotywy najwyższego stopnia emocjonalności i tradycyjnie zaliczane są do nich wykrzykniki, wulgaryzmy lub wyrazy bezpośrednio nazywające uczucia. Konotatywy są takimi emotywami, w których emotywna część znaczenia tylko towarzyszy znaczeniu przedmiotowo-logicznemu i ma charakter konotatywny. Potencjatywy w systemie języka należą do leksyki neutralnej i mogą stać się emotywami w określonych kontekstach i zastosowaniach (Šahovskij 75-76).

Najbardziej złożonym problemem emotiologii jest określenie (wyodrębnienie) relacji emotywnego komponentu znaczenia i myślenia oraz denotatywnego komponentu znaczenia. Wielu badaczy wskazuje na związek zabarwienia emocjonalnego wyrazu z charakterystyką obiektu nominacji (Šahovskij 61) oraz z konkretnymi pojęciami (Stepanov 12; Savčenko 30).

Problem polega na tym, że przedmiotowe i logiczne znaczenie słowa nie zawsze jest tożsame z jego pojęciem. Ma to odzwierciedlenie w hasłach słowników objaśniających, w których treść pojęcia (ze względu na ograniczenie objętości hasła) omówiona jest tylko w pewnym zakresie. Emocjonalne zabarwienie treści pojęcia przekazuje tę wiedzę o świecie, na którą zabrakło miejsca w hasłach słowników objaśniających. Znany rosyjski emotiolog Wiktor Szachowskij ilustruje tę 
niezgodność następującym zdaniem: Piotr jest jak tygrys. Na podstawie słownika objaśniającego zdanie należałoby rozumieć jako: Piotr jest jak 'duży drapieżny ssak z rodziny kotowatych z pasiastym futrem' (Ožegov). Jednak bardziej prawdopodobne są znaczenia: 'Piotr jest okrutny jak tygrys' lub 'Piotr jest zwinny jak tygrys' (Šahovskij 60-61), chociaż okrucieństwo i zwinność tygrysa istnieją tylko implicytnie w językowej świadomości przeciętnego użytkownika języka, natomiast brakuje ich w słownikach objaśniających.

W ramach psycholingwistyki, rozumianej jako dział językoznawstwa badający cechy języka w powiązaniu z myśleniem i życiem społecznym człowieka oraz kolektywu jako warunku niezbędnego do zrozumienia natury jednostek językowych i reguł ich funkcjonowania (Ahmanova 230), powstają słowniki, które w odróżnieniu od tradycyjnych prac leksykograficznych nie są obiektywnym odzwierciedleniem struktury języka, a mentalnego i emocjonalnego stanu przeciętnego użytkownika języka. Należą do nich np. słowniki asocjacyjne, w których przytaczane są reakcje powstające w odpowiedzi na konkretne słowa-bodźce (zob.: Русский ассочиативный словарь, dalej - RSA; Polski słownik asocjacyjny - Gawarkiewicz, Pietrzyk, Rodziewicz). Implicytne właściwości obiektu, nieobecne w słownikach objaśniających, są zarejestrowane w słowniku asocjacyjnym. W haśle słownikowym tygrys znalazły się markery emocji: strach - zły, okrutny, agresywny, ból, zagryzł; podziw - tadny, tadnie, doskonaty, car (RSA 656).

W 2010 roku był wydany inny słownik, który autorzy nazywają lingwistyczno-psychologicznym. Jest to praca Органы чувств, эмоции и прилагательные русского языка (Zmysty, emocje i przymiotniki języka rosyjskiego, dalej ZEPJR). Zarejestrowano w nim rezultaty analizy 15918 przymiotników języka rosyjskiego z punktu widzenia ich związku z odczuciami uzyskiwanymi za pomocą różnych zmysłów. W słowniku znajdują się informacje o „emocjonalności” przymiotników, czyli o tym, na ile przyjemne lub nieprzyjemne emocje wywołuje dany leksem. Z ogólnej liczby wyrazów ankietowani wskazali 475, którym przyporządkowali odczucie przyjemnie/nieprzyjemnie. Wskazane przymiotniki były ponadto ocenione według skali odczuwania emocji: w niskim stopniu (nie)przyjemne, umiarkowanie (nie)przyjemne, bardzo (nie)przyjemne. Stopień odczucia został zaznaczony odpowiednią liczbą - od jednego do trzech - plusów (przyjemne emocje) lub minusów (nieprzyjemne emocje). Trudno przecenić znaczenie takiego słownika i zebranych w nim informacji. Chociaż uważa się, że przedstawiciele różnych kultur przeżywają uniwersalne emocje, to ich jakość i intensywność ukryta pod określonymi jednostkami językowymi funkcjonującymi w różnych wspólnotach kulturowo-językowych może być inna. Emocje są społecznie, kulturowo i historycznie uwarunkowane (Homskaâ, Batova 12), odgrywają ważną rolę w komunikacji międzykulturowej i nieumiejętne ich odczytanie i interpretacja 
mogą zakłócać dialog i prowadzić do konfliktu kultur. Podobnie jak w glottodydaktyce mówi się o kompetencji komunikacyjnej, w emotiologii rozwija się pojęcie kompetencji emotywnej, stopień przyswojenia której decyduje o powodzeniu w komunikacji i działalności translatorskiej.

Celem niniejszego badania będzie ekscerpcja przymiotników ocenionych przez respondentów jako wywołujące bardzo nieprzyjemne odczucia (zaznaczone w słowniku ZEPJR trzema minusami) oraz wyodrębnienie komponentów zabarwienia emocjonalnego ich sememów na bazie danych słownika objaśniającego, słownika asocjacyjnego oraz kontekstów ich użyć w korpusie językowym. W lingwistyczno-psychologicznym słowniku respondenci - młodzi ludzie - ocenili jako bardzo nieprzyjemne (- - ) następujące przymiotniki: вонючий, гнилой, отвратительный, перегарный, потный, протухлыгй, разлагаюший, тошнотный, туалетный, тухлый, фекальный. Starsza grupa respondentów bardzo negatywnie (- - ) oceniła następujące przymiotniki: алкогольный, аммиачный, бранный, взбетенный, визгливый, вонючий, газовый, гнилой, душераздирающий, жуткий, истерический, курительный, курящий, матерный, неприятный, несъедобный, никотинный, одуряющий, отвратительный, перегарный, плесневой, потный, протухлый, разлагающий, ругательный, сальный, сигарный, склизкий, табачный, тошнотный, трухлявый, туалетный, тухлыий, фекальный. Młodsze pokolenie do wywołujących bardzo nieprzyjemne odczucia zaliczyło 11 przymiotników, starsze - aż 34 . Wszystkie przymiotniki ocenione trzema minusami przez młodych ludzi znalazły się w spisie wywołujących bardzo nieprzyjemne odczucia przymiotników wskazanych przez starszych. Może to świadczyć o podobnej waloryzacji przymiotników przez starsze i młodsze pokolenie, wynikającej z jedności językowo-kulturowej, z tendencją do zwiększania się wraz z wiekiem i zdobywanym doświadczeniem liczby znaków językowych wywołujących negatywne odczucia.

Największa liczba (20) „nieprzyjemnych” przymiotników jest odczuwana przez zmysł węchu. Dużą grupę z nich stanowią przymiotniki nazywające zapachy związane z nikotyną i paleniem papierosów (курительнытй, курящий, никотинный, сигарный, табачный), alkoholem (алкогольныгй, перегарный) i innymi używkami (одуряющий). W tej grupie znalazły się też przymiotniki nazywające zapachy będące rezultatem funkcjonowania organizmu człowieka (аммиачный, потный, тошнотный, туалетный, фекальный). Ponadto jako bardzo nieprzyjemne oceniono zapachy związane ze starzeniem się przedmiotów i psuciem się produktów spożywczych (гнилой, плесневой, протухлый, разлагающий, тухлый). Nadrzędnym przymiotnikiem tego pola semantycznego jest hiperonim вонючий.

Inne pole semantyczne tworzą przymiotniki powodujące przykre doznania słuchowe (9). Są one wywołane obraźliwymi, wulgarnymi wypowiedziami 
(бранный, матерный, ругательный), nadzwyczajnymi sytuacjami, w których zaistniały (взбешенный, истерический), lub nieprzyjemną jakością dźwięków (визгливый, дущераздирающий). Hiperonimami tego pola są przymiotniki жуткий, неприятный.

Zmysły smaku, wzroku i dotyku są reprezentowane w słowniku znacznie skromniej - po 4 leksemy, przy czym grupy leksykalno-semantyczne, podobnie jak dla zapachów i dźwięków, są tworzone przez jednostki nazywające rezultaty funkcjonowania ludzkiego organizmu, nadzwyczajnych zachowań człowieka i starzenia się produktów żywnościowych:

wzrok - взбешенный, курящий, отвратительный, сальный;

dotyk - потный, сальный, скользкий, трухлявый;

smak - алкогольный, несъедобный, отвратительный, тухльй.

Emotywny komponent semantyki tych przymiotników może być ukryty w semach różnych rodzajów. Mogą to być:

1) semy emotywne, za pomocą których człowiek wyraża swoje emocje. Ich markerem w definicjach słownikowych są semy-indykatory (uczucie, emocja) lub nazwy konkretnych emocji - semy-kwalifikatory (pogarda, życzliwość), czyli afektywy;

2) semy ekspresyjne, za pomocą których nadawca wywiera wpływ na myśli i uczucia odbiorcy. Markerami takich semów w definicjach słownikowych są elementy 'bardziej', 'bardzo';

3) semy oceniające (apresemy), za pomocą których nadawca dokonuje subiektywnej oceny referenta. Można je wyodrębnić dzięki kwalifikatorom (np.: dobry, zły) w definicjach słownikowych (Šahovskij 334-335).

Pierwsza grupa analizowanych przymiotników ma status afektywów i semantykę emotywną o charakterze denotatywnym. Należą do nich hiperonimy вонючий, жуткий, неприятный oraz te leksemy, w których znaczeniu odnajdujemy semy waloryzacji i emotywności (w tekście pogrubione) $)^{1}$ :

вонючий - 'дурно, неприятно пахнущий';

неприятный - 1) 'не нравящийся своими качествами, свойствами';

2) 'вызывающий чувство неудовольствия, огорчения, неловкости';

жуткий - 'вызывающий чувство страха, ужаса'; 'тягостный, неприятный';

отвратительныц - 1) 'вызывающий отвращение'; 2) 'очень плохой, скверный, гадкий';

взбешенный - 'охваченный бешенством, находящийся в состоянии крайнего раздражения’;

${ }^{1}$ Wszystkie objaśnienie pochodzą z MAS, źródło elektroniczne. 
визгливылй - 1) 'пронзительно-резкий, сопровождаемый визгом'; 2) 'часто издающий визг';

гнилой - 1) 'испорченный или разрушенный гниением; гниющий, разлагающийся'. 'Испорченный, несвежий, затхлый (о воде)'; 2) 'сырой, дождливый, туманный (о погоде, климате)'; 3 ) перен. 'порочный в каком-л. отношении'. 'Общественно вредный, нездоровый, упадочнический';

трухлявый - 'превращающийся в труху от гнили, ветхости';

душераздирающий - 'ужасный, полный отчаяния, страдания';

истерический - 1) прил. к истерия, к истерика; 2) 'склонный к истерии, подверженный истерии'; 3 ) 'характерный для истерии, для истерика; такой, как при истерике’; 4) 'болезненно-страстный, судорожный, доходящий до истерики';

матерныци - 'содержащий в себе непристойно оскорбительное употребление слова мать';

несъедобныцй - 'непригодный для еды';

тухльый - 1) 'загнивший и издающий дурной запах; протухший'; 2) 'свойственный гниющему, истлевающему предмету (о запахе)'; 3 ) 'затхлый, несвежий (о воде)'; 4) 'прогорклый (о масле)';

газовыл ный с применением отравляющих газов;

разлагающий - способствующий разложению, внутреннему распаду, упадку, ведущий к ним.

W objaśniających hasłach słownikowych przytoczonych leksemów wyróżniamy semy emocji (пр.: ‘огорчение', 'неудовольствие', 'страх', ‘раздражение', 'отчаяние', 'страдание') oraz semy waloryzacji (np.: 'ужасный', 'вредный', 'плохой', 'скверный', ‘упадок', 'гниль').

Część przytoczonych przymiotników należy zaliczyć do konotatywów, ponieważ emotywne semy mają implicytny charakter i są zlokalizowane poza granicami ich logiczno-przedmiotowego znaczenia. Łatwo jednak odtworzyć ich emotywność przez wyodrębnienie jej w rzeczownikach, przez które są definiowane w słownikach objaśniających:

перегарный - прил. к перегар. Перегар - 'неприятный запах изо рта от выпитого накануне спиртного';

одуряющий - 'вызывающий одурение, помрачающий сознание'. Одурение - 'утрата способности ясно воспринимать и понимать окружающее';

ругательный - 'являющийся руганью, содержащий в себе ругань'. $Р$ гань - 'слова, которыми ругают, сквернословие'. Сквернословие - 'речь, наполненная неприличными выражениями, непристойными словами, бранью';

бранныци - 'ругательный' (jw.); 
плесневой - 1) прил. к плесень; 2) 'образующий плесень'. Плесень - 'бархатистый пушистый налет на чем-л. гниющем, влажном, представляющий собой скопление микроскопических грибков'; 2) 'налет, проявление чего-л. отрицательного, застойного, вредного';

тошнотный - 1) прил. к тошнота. Тошнота - 'неприятное, томительное ощущение, предшествующее рвоте, а также состояние того, кого позывает к рвоте; дурнота'; 2) 'тошнотворный'.

Drugą grupę konotatywów stanowią leksemy, których waloryzacja nie jest uwidoczniona w haśle słownikowym, np.:

алкогольныц - 'содержащий алкоголь. Вызываемый алкоголем';

аммиачный - 'содержащий аммиак';

курительный - 'предназначенный для курения';

курящий - 'такой, который курит';

никотинныци - 'обусловленный, вызванный никотином';

потныцй 1) 'покрытый потом; вспотевший'; 2) 'пропитанный потом'; 3) 'покрытый влажным налетом, каплями осевшего пара; запотевший’;

сальный - 1) 'сделанный из сала; оставленный салом, жиром (о пятнах, следах и т. п.)'; 2) 'предназначенный для получения сала; с высоким, большим содержанием сала'; 3) 'залитый или испачканный чем-л. жирным, лоснящийся от жира, грязи';

сигарныц - прил. к сигара;

склизкий - 1) 'покрытый слизью; ослизлый'; 2) 'скользкий’;

табачныц̆ -1) прил. к табак; 'сделанный, полученный из табака; относящийся к выращиванию, обработке табака или к торговле табаком’;

туалетный - 1) прил. к туалет; 'служащий для совершения туалета';

фекальный - прил. к фекалии; 'содержащий фекалии; предназначенный для фекалий'.

W przypadku braku emotywnych semów w objaśniających definicjach słownikowych przytoczonych przymiotników możliwe jest ich odnalezienie w polach asocjacyjnych odpowiednich znaków językowych. Przymiotniki ocenione przez respondentów jako bardzo nieprzyjemne powinny wywoływać negatywne skojarzenia. W asocjacyjnym słowniku języka rosyjskiego (RSA 2002) nie zarejestrowano wszystkich badanych przymiotników, dlatego rozpatrywano także skojarzenia dotyczące odpowiednich rzeczowników, będących formami podstawowymi dla przymiotników. Badaniu nie zostały poddane formу аммиачный/аммиак, курительный, курящий, никотинный/никотин, сигарный/сигара, фекальный/фекалии ze względu na ich brak w słowniku asocjacyjnym.

W polach asocjacyjnych konotatywów пот, табак, туалетное znajdują się reakcje wyrażające skojarzenia z nieprzyjemnym zapachem: 
nom - запах, вонючий, вонь, воняет, выделение, едкий, неприятно, неприятный, фу!

табак - вонючий, противно, вонь;

туалетное - вонючее, нерпиятный запах.

Konotatywy сало і склизкий kojarzą się z nieprzyjemnymi doznaniami, bez wskazania na zmysł:

сало - невкусное, гнилое, отвратительное, фу!

склизкий - противный, мерзкий, неприятный, гадкий, гадость.

Badane wyrazy, mimo zakwalifikowania ich przez respondentów do zdecydowanie nieprzyjemnych (-- ), według danych słownika asocjacyjnego wywołują także pozytywne reakcje:

алкоголь - благо, хорошо, классно, помогает жить;

сало - свежее, вкусное;

табак - душистый;

туалетное - душистый.

Można zauważyć także przełożenie uświadomionego niebezpieczeństwa i zagrożenia dla zdrowia na negatywne odczucia związane ze zmysłami. Przymiotniki алкогольныци і табачный, ocenione jako bardzo nieprzyjemne węchowo i smakowo, w słowniku asocjacyjnym oceniane są przede wszystkim jako szkodliwe dla zdrowia:

алкоголь - вред, вреден, зло, болезнь, враг здоровья, отвращение, плохо, приносит вред организму, тошнота;

табак - вредный, болезнь, рак.

Niewykluczone, że z takim samym procesem przełożenia wiedzy o szkodliwości używek dla zdrowia na nieprzyjemne odczuwanie mamy do czynienia w konotacjach przymiotników курительный, курящий, никотинный, сигарныци.

Na podstawie słownika ZEPJR możemy stwierdzić, że użytkownikom języka rosyjskiego przymiotnik сигарный kojarzy się z bardzo nieprzyjemnym doznaniem węchowym. Niestety, brak jednostki сигарныци w słowniku asocjacyjnym uniemożliwia prześledzenie łańcucha skojarzeń wywołanych tym słowem i wyodrębnienie semów negatywnej waloryzacji. Odszukanie komponentów znaczenia o zabarwieniu emocjonalnym wydaje się możliwe tylko w rezultacie prześledzenia użyć korpusowych.

W Narodowym Korpusie Języka Rosyjskiego (Национальный корпус русского языка, dalej - NKJR) najczęstszymi kolokacjami są: сигарный дыıм, сигарнылй клуб, ponadto odnotowujemy połączenia: сигарнылй чемпионат, сигарный журнал, сигарный ящчик, сигарный магазин, сигарный окурок, сигарный лист, сигарный сок, сигарныий шкафчик, сигарный пепел, сигарный мундштук, сигарный столик, сигарный футляр. 
W NKJR przymiotnik сигарный odnotowujemy w kontekstach mówiących bezpośrednio o jego przykrym zapachu (вонь от его сигар; Через несколько минут все купе было полно вонючим удушливым сигарным дымом; Воздух гостиной отдавал застоявшимся сигарным дымом), który wywołuje nieprzyjemne doznania (Едкий сигарный дым; поперхнулся жирным сигарным дымом; глаз прищурен от сигарного дыма; Вязкий сигарный дым; Отпугивает детишек) i stanowi poważne zagrożenie dla zdrowia (Мой oтеu рассказывал, что однажды, будучи еще совсем маленьким, я упал в обморок от его сигарного дыма). Nieprzyjemny zapach i zjadliwość dymu przeciwstawia się świeżemu powietrzu (Сигарный дым вместо свежего воздуха; Воздух был мутно-сиреневый от сигарного дыма; Он распахнул окно). Negatywna waloryzacja przejawia w zestawieniu z pesymizmem i niepozytywną oceną przyszłości: Будущее из пессимизма и сигарного дыма - скверная вещь! I chociaż odnajdujemy pozytywnie waloryzowane konteksty, w których dym z cygara opisany jest jako wykwintny symbol przynależności do wyższych klas (изысканно-сигарным дымом; Судя по его размашистому почерку с завитушками и тонкому сигарному запаху, он был нечужд европейской иивилизации), tо liczebnie znacznie ustępują one kontekstom z negatywną waloryzacją przymiotnika сигарный.

Przeprowadzone badanie wykazało, że informacja o zabarwieniu emocjonalnym przymiotnika zarejestrowanego $\mathrm{w}$ ZEPRJ nie zawsze jest zawarta $\mathrm{w}$ haśle słownika objaśniającego. W takim przypadku wyodrębnienie emotywnych semów umożliwiają dane słownika asocjacyjnego lub analiza użyć przymiotnika w korpusach językowych. Emotywne semy funkcjonują jako afektywy wskazujące na kompleksy związanych z danym słowem doznań i odczuć. Analiza ta może być wykorzystana $\mathrm{w}$ rekonstrukcji emocjonalnych obrazów świata i narodowo-kulturowej specyfiki wyrażania emocji oraz kształtowania emotywnej kompetencji i osobowości, a metodyka wyodrębnienia emotywnego komponentu znaczenia za pomocą afektywów-skojarzeń może posłużyć do dalszych badań emotywnej leksyki.

\section{Bibliografia}

Ahmanova, Ol'ga S. Slovar' lingvističeskih terminov. Moskva, KomKniga, 2005.

Apresân, Ûrij D. „Obraz čeloveka po dannym âzyka: popytka sistemnogo opisaniâ”. Voprosy âzykoznaniâ, 1, 1995, s. 37-65.

Babenko, Lûdmila G. Leksičeskie sredstva oboznačeniâ èmocij v russkom âzyke. Sverdlovsk, Izdatel'stvo Ural'skogo universiteta, 1989.

Balli, Šarl'. Obŝâ̂ lingvistika i voprosy francuzskogo âzykoznaniâ. Moskva, Izdatel'stvo inostrannoj literatury, 1955. 
Daneš, František. „Cognition and Emotion in the Discourse Interaction: A Preliminary Survey of the Field". Preprints of the Plenary Session Papers. XIV International Congress of Linguists Organized under Auspices of CIPL, 10-15 August 1987. Berlin, 1987, s. 272-291.

Gak, Vladimir G. Âzykovye preobrazovaniâ. Moskva, Âzyki russkoj kul'tury, 1998.

Galkina-Fedoruk, Evdokiâ M. „Ob èkspressivnosti i èmocional'nosti v âzyke”. Sbornik statej po âzykoznaniû. Red. Aleksej I. Efimov. Moskva, Izdatel'stvo Moskovskogo universiteta, 1958, s. $103-124$.

Gawarkiewicz, Roman, Izabela Pietrzyk, Barbara Rodziewicz. Polski słownik asocjacyjny z suplementem. Szczecin, Print Group, 2008.

Grabias, Stanisław. Język w zachowaniach społecznych. Lublin, Wydawnictwo Uniwersytetu Marii Curie-Skłodowskiej, 1997.

Homskaâ, Evgeniâ D., Natal'â Â. Batova. Mozg i èmocii. Nejropsihologičeskoe issledovanie. Moskva, Rossijskoe pedagogičeskoe izdatel'stvo, 1998.

Kerbrat-Orecchioni, Catherine. La connotation. Lyon, Presses universitaires de Lyon, 1977.

Kožina, Margarita N. Stilistika russkogo âzyka. Moskva, Prosveŝenie, 1983.

Lubaś, Władysław. Polskie gadanie. Podstawowe cechy i funkcje potocznej odmiany polszczyzny. Opole, Wydawnictwo Uniwersytetu Opolskiego, 2003.

Mâgkova, Elena Û. „Problemy i perspektivy issledovaniâ èmocional'nogo značeniâ”. Âzyk, soznanie, kommunikaciâ: Sbornik statej, vyp. 11. Red. Viktoriâ V. Krasnyh, Andrej I. Izotov. Moskva, Dialog-MGU, 2000, s. 20-23.

MAS - Malyj akademičeskij slovar'. Red. Anastasiâ P. Evgen'eva. Moskva, Russkij âzyk, 1981-1984. Web. 15.03.2020. http://enc.biblioclub.ru/Encyclopedia/118_malyj_akademicheskij_slovar.

Maslečkina, Svetlana V. „Vyraženie èmocij v âzyke i reči”. Vestnik Brânskogo gosudarstvennogo universiteta, 3 (26), 2015, s. 231-236.

Nelûbin, Lev L. Očerki po vvedeniû v âzykoznanie. Moskva, Moskovskij gosudarstvennyj oblastnoj universitet, 2005.

NKJR - Nacional'nyj korpus russkogo âzyka. Web. 17.02.2020. http://www.ruscorpora.ru/new/.

Ožegov, Sergej I. Slovar' russkogo âzyka. Web. 15.02.2020. https://slovarozhegova.ru/.

RSA - Karaulov, Ûrij N. et al. Russkij associativnyj slovar'. Tom I: Ot stimula k reakcii. Moskva, Izdatel'stvo AST, 2002.

Šahovskij, Viktor I. Lingvističeskaâ teoriâ èmocij. Moskva, Gnozis, 2008.

Savčenko, Aleksej N. „Âzyk i sistemy znakov”. Voprosy âzykoznaniâ, 6, 1972, s. 21-32.

Stepanov, Ûrij S. Osnovy obŝego âzykoznaniâ. Moskva, Prosveŝenie, 1975.

Vežbickaâ, Anna. Semantičeskie universalii i bazisnye koncepty. Moskva, Âzyki slavânskih kul'tur, 2011.

ZEPJR - Kolbeneva, Marina G., Ûrij I. Aleksandrov. Organy čuvstv, èmocii i prilagatel'nye russkogo âzyka. Lingvo-psihologičeskij slovar'. Moskva, Âzyki slavânskih kul'tur, 2010.

Zvegincev, Vladimir A. Semasiologiâ. Moskva, Izdatel'stvo Moskovskogo universiteta, 1957. 